
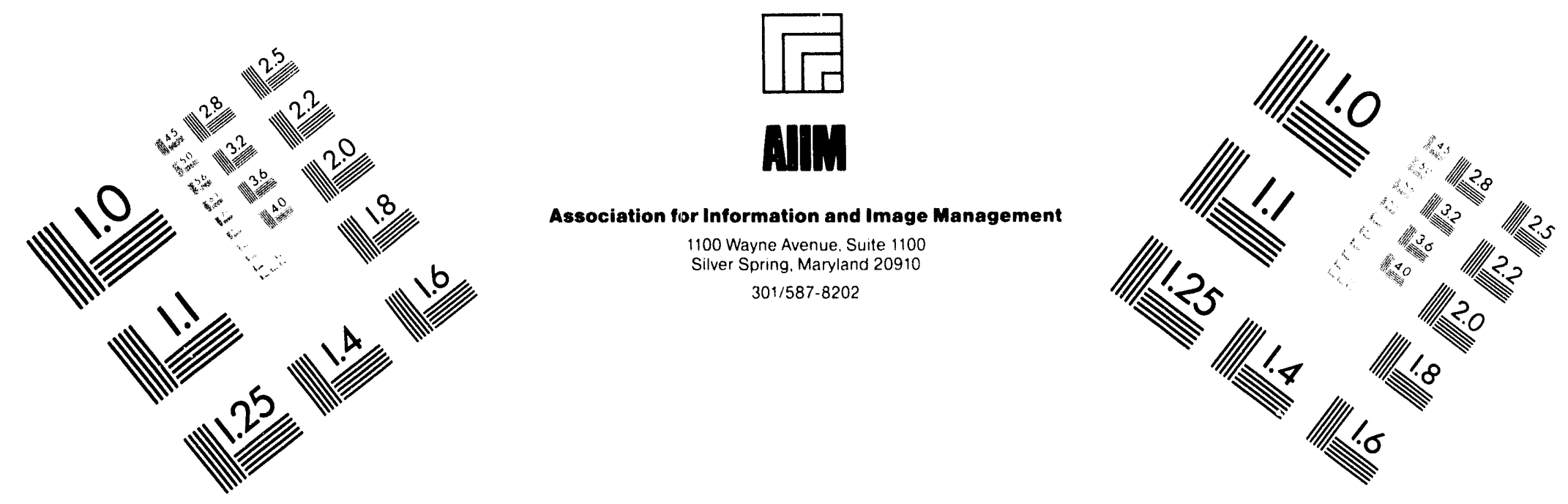

\title{
Centimeter
}

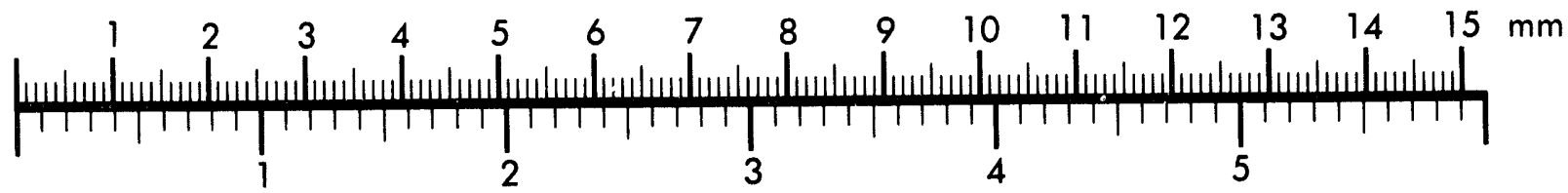

Inches
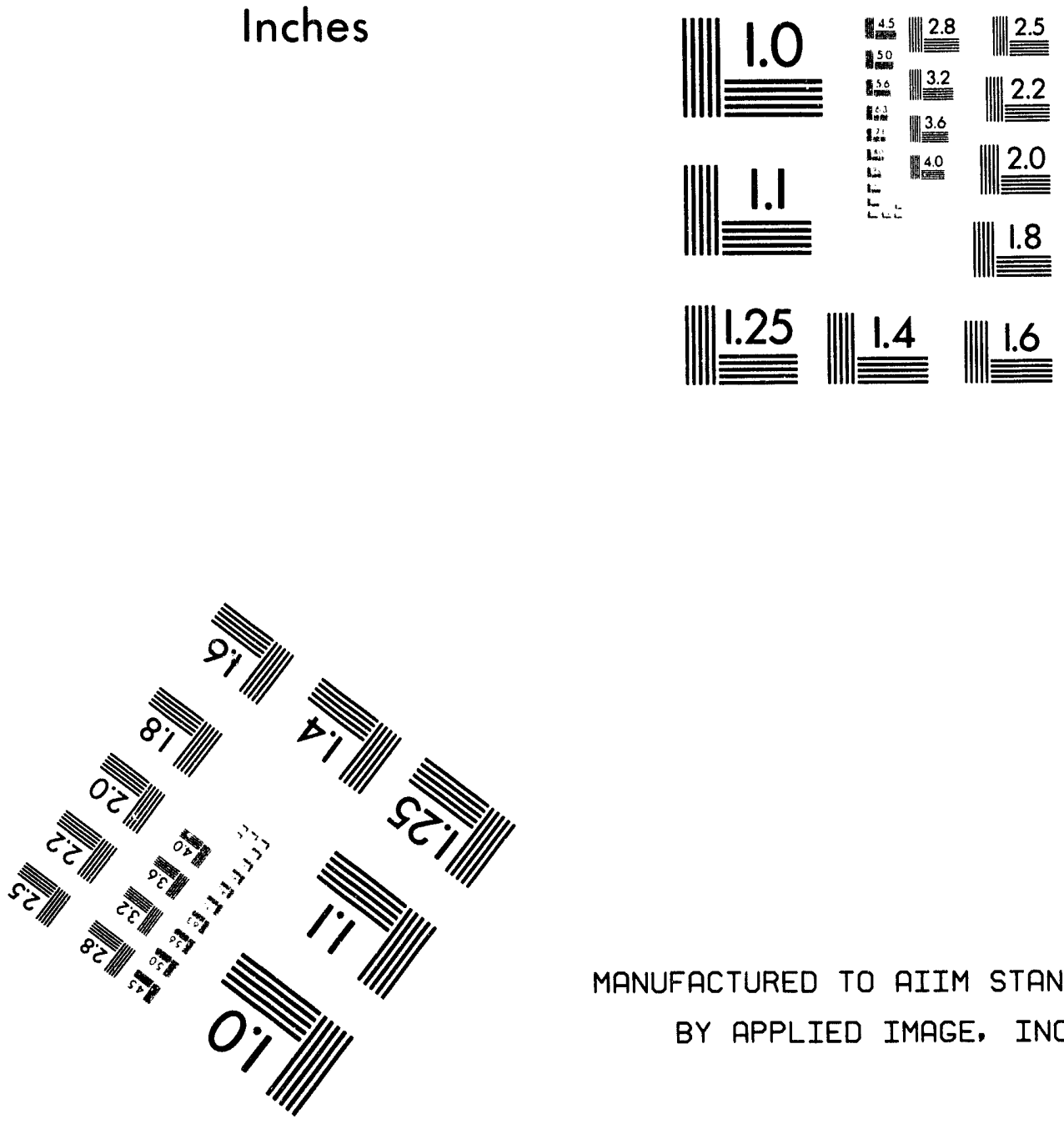

MANUFACTURED TO AIIM STANDARDS

BY APPLIED IMAGE, INC.

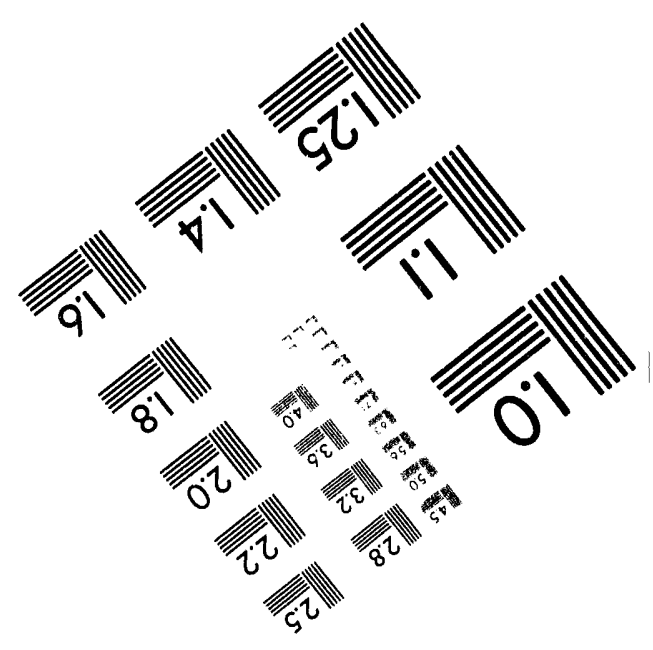



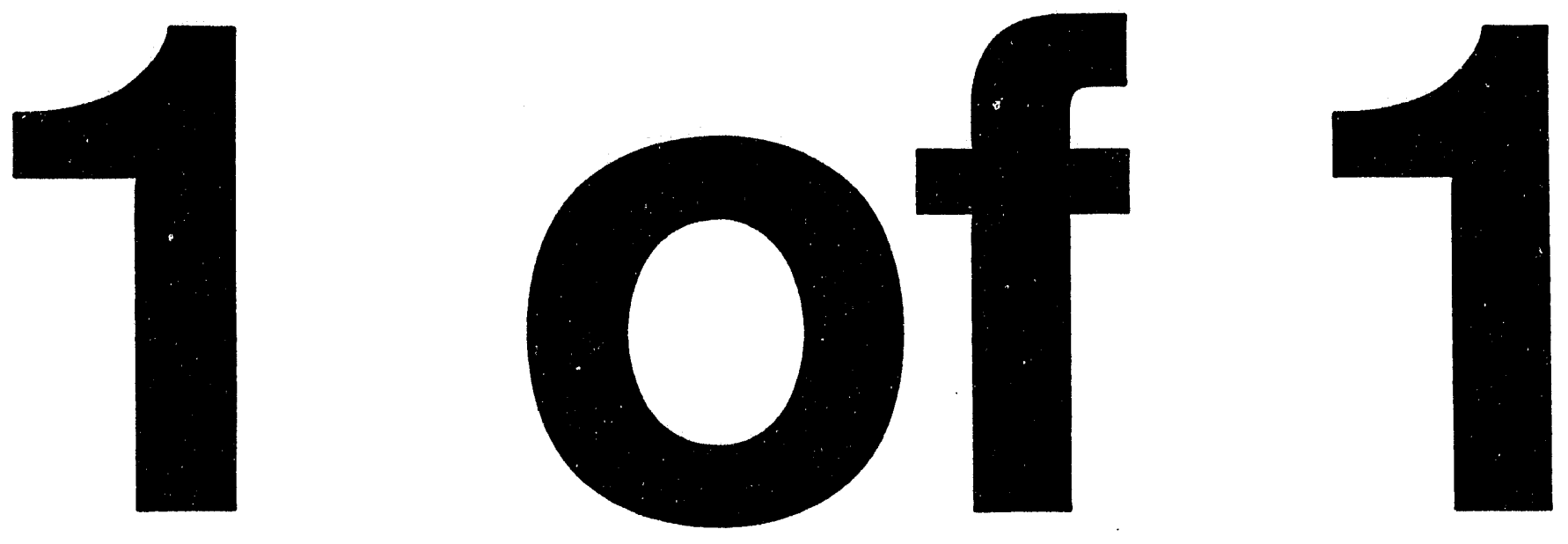

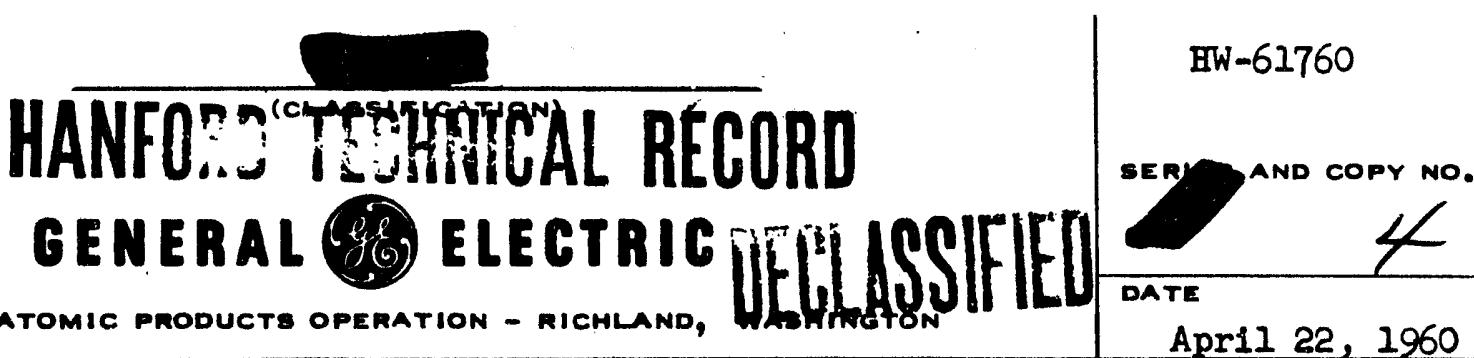

MANFORD ATOM

April 22, 1960

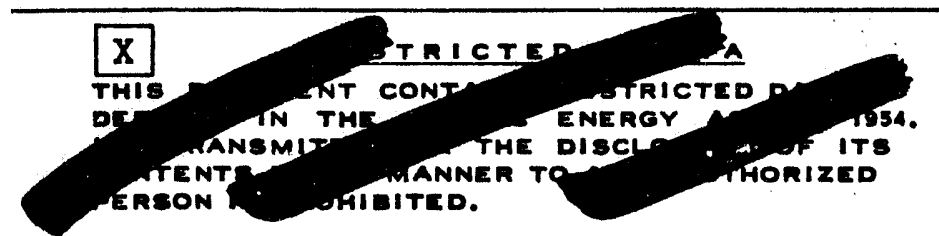

OTHER OFFICIAL CLASBIFIED INFORMATION.

THIS MATERIAL CONTAINS INFORMATION AFFECTING

THE MATIONAL DEFENSE OF THE UNITED STATE

WITHIN THE MEANING OF THE EBPIONACE LAWE,

TITLE 16, U.8.C., SECS. TO3 AND 794, THE TRANS-

MISSION OR REVELATION OF WHICH IN ANY MANNER

TO AN UNAUTHORIZED PERSON IS PROHIBITED EY

LAW.

\section{PONHIVIAL FOR PROCESS TUBE BURNOUT DURING TRANSIENT CONDITIONS}

THIS DOCUMENT MUM TLFT UNATTENDED THIS DOCUMENT MUS
TO IT. WHEN NO
GUARDED AN CLABSI TLES, IT IS YOUR THIS CT AND FROM. ANY CCT AND FROM. ANY
DENCE IS PROMI WIZED PERSON.
WITE TO UNOVED LOCKED RE PON" AUTHOR

P. A. CARLSON 3. S. JONES GIPUINGEHE
KLUEIINGD 300 AREA JUN2 31960 KLIUKN TO MIN THEM FROM O SION IN THL

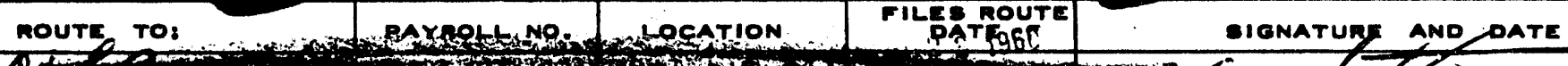

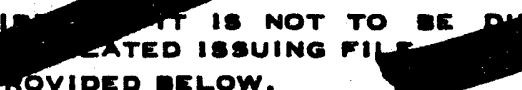
KEEP IT YOU HAYS T SIGNED RECE
TL TO, AND STORACN

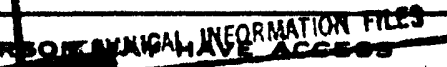
TAN APPROVED TAL TO, AND STONAC
TE ADDITIONAL InE REQUINED,

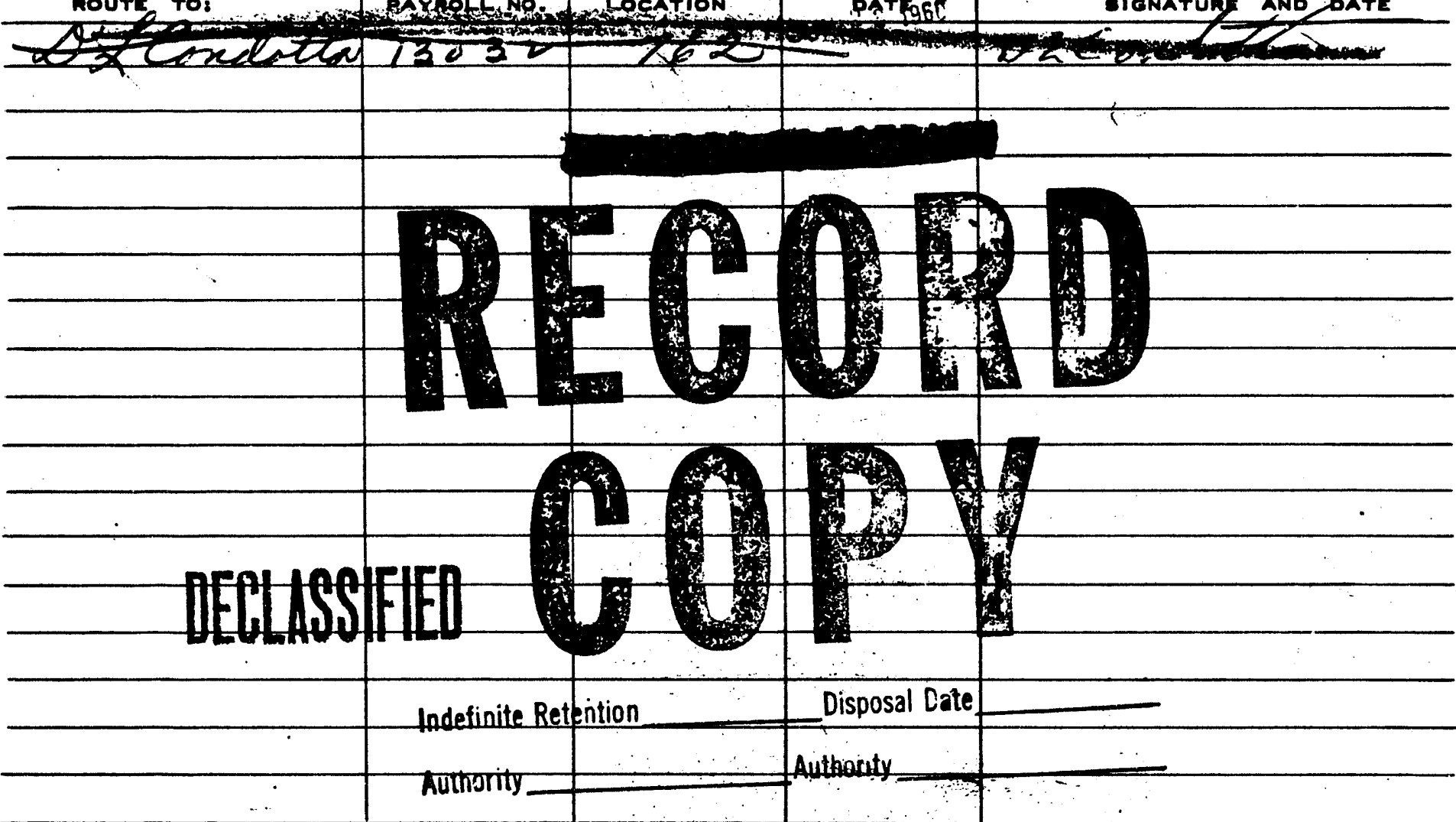
SA-3000-340 (3-5n) alte-or nicmLamo. wasm. 


\section{DECLASSFFED}

DISTRIBUTION

1. J. M. Batch
2. J. H. Brown
3. P. A. Carlson
4. D. L. Condotta
5. G. C. Fullmer
6. S. M. Graves
7. O. B. Greager
8. A. B. Greninger
9. H. W. Heacock
10. S. S. Jones
11. K. W. Norwood
12. R. W. Reid
13. R. E. Trumble
14. Record Center
15. 300 F1les
16-80. Extra

DISCLAIMER

This report was prepared as an account of work sponsored by an agency of the United States Government. Neither the United States Government nor any agency thereof, nor any of their employees, makes any warranty, express or implied, or assumes any legal liability or responsibility for the accuracy, completeness, or usefulness of any information, apparatus, product, or process disclosed, or represents that its use would not infringe privately owned rights. Reference herein to any specific commercial product, process, or service by trade name, trademark, manufacturer, or otherwise does not necessarily constitute or imply its endorsement, recommendation, or favoring by the United States Government or any agency thereof. The views and opinions of authors expressed herein do not necessarily state or reflect those of the United States Government or any agency thereof.

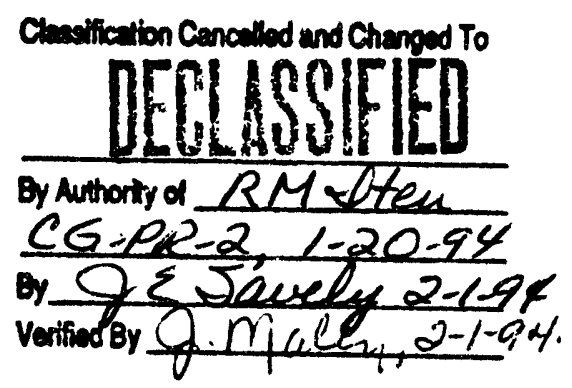

\section{IRRADIATION PROCESSING DEPARTMENT}

Apr11 22, 1960
This document consists of 23 pages. No. $\longleftarrow$ of 80 copies.

This document eiassifiga by:

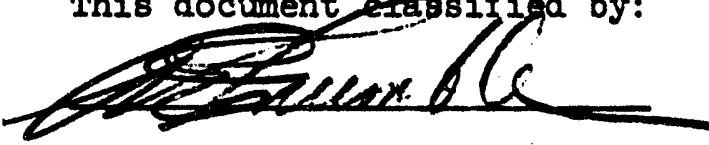




\section{DECLLSSFIIED}

\section{TABLE OF OONTENTS}

Page

1. Introduction ..................... 3

2. Summary and Concluslons ................. . 3

3. Discussion .................... 4

3.1 History of Burnout Protection .............. 4

3.2 Present 8tatus ................ . 6

3.2.1 Exper1mental studies . . . . . . . . . . 6

3.2.2 Anslyt1cal Methods . . . . . . . . . . . 7

3.2.3 Transient. Events with Potential for Burnout . . . . II

3.2.4 Research and Development Programs . . . . . . . 18

4. Acknowledgements . . . . . . . . . . . 18

References .......................... 19

Append1x . . . . . . . . . . . . . . . . . . . . 20

\section{IIST OF FIGURES}

1. K-Reactor BPA Loss, Effect of Flow Instab1lity at Constant Power . 14

2. K-Reactor Pump Loss, Effect on Flow Instability at Current Power . 15

3. K-Reactor Power Surge, Effect on Flow Instablilty at Constant

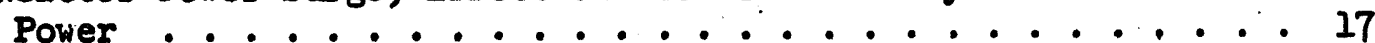

A-1. Bolling Curve ................. 20

A.2. Experimental $R$ sults of T1me vs Pressure for Case of Sudden Flow

Loss in $\mathrm{K}$ Geometry . . . . . . . . . . . . . . . 23 
1. INTRODUCTION

\section{DECLLSSFFED}

The potential for inadequate heat removal within a process tube which might result from accidental flow decrease or power level increase is of the utmost importance in evaluating reactor hazards. The events which might cause a flow decrease or power surge in a process tube are varled, and may generally be classed as 2) those that affect only a single process tube, and 2) those which affect all or a large portion of the tubes in the reactor. A great deal of time and effort have been devoted to the study of the flow, pressure, and temperatures within a process tube during events affecting single tubes. $(1-5)$

This report is an interpretation of these data as applied to the most severe (rapid) K-Reactor transients which are credible. These transients would result from such abnormal and Improbable events as: 1) sudden power level surge, 2) primary power fallure, and 3) sudden loss of flow from one or more pumps such as might occur in a plpeline rupture or pump shaft fallure. Present reactor power levels and existing pumps are considered. The cases covered in this document assume; the avallability of secondary power in the case of BPA fallure, and no loss of power for the pump loss and power surge cases. The extremely improbable case of 1988 of both primary and secondary power is the subject of another report. $(10)$

The transient conditions existing durling these accidental events are more severe at the K-Reactors than those existing under similar transients in the other Hanford reactors. At the B, D, DR, F, H, and C Reactors no fuel channel burnout will occur during primary power fallure or sudden loss of flow from one or two process pumps. Also, the potential for burnout in the case of a power surge is less than at the K-Reactors because of lower equilibrium power levels and because of greater assurance of early reactor scram due to a more rapid Panellit response to the increased pressures accompanying a power level increase. Therefore, this document reviews the K-Reactor transient burnout since it represents the most severe case.

2. SUMMARY AND CONCLUSIONS

The power level and coolant flow rate of the reactor are so coordinated that a factor of safety of greater than two exists between the actual heat flux and the heat flux at whlch film bolling at the surface of the fuel element could occur. However, during a transient condition the potential for burnout will change. The effects of these changes are considered in this report.

Analyses indicates that no fuel channel burnout will result from'a BPA power 1088 to the process pumps. For the case of the sudden loss of a single $\mathrm{K}$ process low-lift or high-Ilft pump no burnout problem exists during six or five pump operation. For the extremely improbable case of the simultaneous loss of two process pumps some fuel channel burnout could occur. The fact that very severe flow reduction tests have been run in the laboratory without fuel rod burnout is very encouraging. However, a quantitative transfer cannot be made in all cases between the single tube laboratory results and the multiple tube reactor. 
In the case of a local accidental power level surge the Panellit system provides the primary protection against fuel jacket melting. An analysis by G. R. Parkos (unpublished) indicates that a 70 - $90 \%$ local power level surge is possible at the K-Reactors in the case of inadvertent withdrawel of a top control rod or accidental alscharge of a top polson column. Although flim bolling conditions are expected to occur in $\mathrm{K}$ process tubes at power level increases well below these values (28\% for the 5-pump case, and 35\% for the 6-pump operation), a Panellit gage high-trip 1s expected to shut the reactor down before jacket melting occurs. This is assured if there is no significant multiple tube effect. The occurrence of such a power surge incident would require a gross operating error or fallure of a piping component which is not unduly stressed. Further control over the magnitude of power surges w1ll be obtained from Improved nuclear instrumentation scheduled. for installation.

The future program in this area consists of continued periodic review of transient burnout conditions at the Hanford reactors in advance of increasing the severity of operating conditions. In addition, continued and expanded experimental studies are being made to evaluate total reactor as well as single tube events.

\section{DISCUSSION}

\subsection{History of Burnout Protection}

During normal reactor operation the cooling provided to a process tube is sufficlent to remove large quantities of heat without experiencing high fuel element temperatures. With a reduction in flow or power increase these conditions are changed so that coolant bolling may occur in the process tube and rear fittings, which increases the pressure drop across the tube. At some value of flow reduction or power increase the coolant supply is inadequate to overcome the increased resistance to flow and the flow rate drops to a very low rate soon after the instant of change. If the reactor is not shut down when this unstable flow condition occurs, film bolling takes place on downstream fuel elements and jacket melting may occur because of the Increased resistance to heat transfer. The Hanford problem in preventing bolling burnout, then, has been to operate the reactors to assure the stablilty of the coolant flow, and to shut down rapidly when conditions of inadequate flow occur.

Since the Initial startup of the Hanford reactors, several methods have been used to specify process tube outlet temperature limits that assure 
the stability of the coolant flow. Initially, the reactors were operated under excess header pressure limits. This required that sufficient Iront header pressure be avaliable to yleld a supply pressure $23 \%$ above the peak of the theoretical bolling curve. With this high pressure avallable the Panellit tube inlet pressure monitoring system was kept on automat1c alsrm and manual scram after 20 seconds. Thus, in the event of serlous but temporary flow stoppages, the avallable process water pressures would be sufficient to sweep out any steam formed by, bolling in the tube. The fallacy of this concept was that the flow Interruptions may not necessarily be temporary in nature, and that unstable boling, and possible fuel element melting could occur without automatic $8 \mathrm{cram}$ of the reactor.

With the installation of improved Panelilt gages and the recognition of this situation, a new concept was developed that relied upon automatic reactor scram when Panellit trip limits were exceeded and at the same time eliminated the excess header pressure requirement. Th1s led to the "trip-before'bolling'limit" which was adopted after It had been shown that by rather simple changes in Panellit gage trlp settings, tube power limits could be increased with greater safety than had been provided by excess header pressure limits with no automatic reactor scram. Rellance was placed on the Panellit gages to detect any type of flow reduction. These Panellit trip points were set 80 that a reactor scram was automatically initiated when the tube flow was reduced to a value slightly greater than that required to cause tube outlet temperatures to reach rear crossheader saturation temperature. Thus, it was thought that the flow rate which caused bolling at this point in the flow system was the instability flow rate. The next step, operation under "trip-before-instability" Ilmits, was instituted when it was shown that the Ins tability flow rate, or the flow rate corresponding to the minimum point of the bolling curve, was not the same as the bolling flow rate. Since the basic concern in the concept is instablilty, the bolling terminology was dropped, and limits were developed on the besls of 1nstability. It should be emphasized that, conceptually, there is no difference between trip-before-bolling and trip-before-instablilty because they both rely on the Panellit gage to inftiate a reactor scram at the time of an individual tube flow reduction. The only difference in the two is that some of the conservatism in the former limit was removed when further knowledge revealed that the reactor power levels were unnecessarily restricted by 1 ts use. .

Further improvements in the pressure monitoring system and a considerable back-10g of experimental data showed that this.11mit, too was extremely conservative. Currently the reactors are operated by the "trip-afterInstablilty" IImit. This limit is also conceptually the same as the earlier trip-before-bolling" linit, and relles on the Panellit gage to detect flow reductions of sufficlent magnitude to bring on unstable flow rates. The terminology is based on the fact that the laboratory data 
which revealed the large amount of conservatism in the trip-beforeinstability limit also showed that even in the event of a partial flow reduction sufficlent to cause boiling and flow instability the reactor could be safely scrammed. This occurs because: pressurization from bolling in the tube outlet.fittings will initiate a high pressure trip in time to prevent slug jacket melting. The terminology is, in fact, erroneous because low trip protection from rapid upstream plugIng events is conservatively applied to trip before instability and the trip after instability remains as backup.

\subsection{Present Status}

\subsubsection{Experimental Studies}

A large number of experiments have been made in the Thermal Hydraulics Laboratory to determine the flow and pressure reLationship which exists in a process tube during both steady state and accidental transient operations at the K-Reactors. (1-5) These tests were made on a full scale model of a K-Reactor process tubo, 1.0,y ribbed tabe, and an electrically heated simulated fuel column. Flow reductions were accomplished with the use of quick acting valves in the supply piping. From the steady-state experiments an estimate may be made of the instantaneous flow and pressure at the point where film bolling begins in the process tube and at the point of the initiation of flow instability. Most recent data are shown in Table I.

\section{TABLE I}

BURNOUT CONDITIONS IN A K REACTOR PROCESS TUBE*

\begin{tabular}{|c|c|c|c|c|c|}
\hline Tube & Inttial & Tube & \& Flo & Reduction to I & tlate \\
\hline $\begin{array}{c}\text { Power } \\
\text { kw }\end{array}$ & $\begin{array}{r}\text { Flow } \\
\text { gTom }\end{array}$ & $\begin{array}{c}\text { Temperature } \\
\text { RIse, }{ }^{\circ} \mathrm{C}\end{array}$ & $\begin{array}{l}\text { Instability- } \\
\text { Rapid Loss }\end{array}$ & $\begin{array}{l}\text { Instability- } \\
\text { Gradual Loss }\end{array}$ & $\begin{array}{l}\text { Film } \\
\text { Bolling }\end{array}$ \\
\hline 1000 & 36.1 & 105 & $24 \%$ & $52 \%$ & $67 \%$ \\
\hline 1250 & 47.4 & 100 & $19 \%$ & $37 \%$ & $67 \%$ \\
\hline 1500 & 54.2 & 205 & $16 \%$ & $24 \%$ & $63 \%$ \\
\hline
\end{tabular}

*Source: HW-54369 and EW-64029

NOTES: Supply pressure is constant at 325 psig. Inlet temperature 18 approximately $20^{\circ} \mathrm{C}$. Graphite moderator sensible heat neglected. 


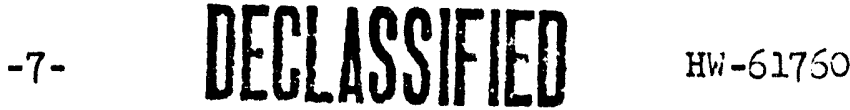

These data, then, indicate the flow reduction at which unstable flow conditions are initiated in the tube as a result of either a gradual or rapld flow loss at a constant supply pressure. At a lower supply pressure these flow rates would be higher and instabllity would occur at lower percentage flow reductions. They also show the relationship between burnout conditions and the conditions at which flow Instablifty is initiated in the process tube. Thus, a certain amount of time is avallable for shutdown, after flow instability starts in the process tube before burnout conditions are reached. The time sequence has been investigated in transient experiments in which the following types of Individual tube events were covered:

a) Plugging upstream of the flow measuring orlfice or venturi.

b) Plugging downstream of the active charge.

c) Loss of front or rear pigtail.

d) Loss of front header pressure such as the effect of a process pump fallure or a process line rupture.

e) Loss of pumping power.

f) Tube power level surge above normal operating conditions.

These experiments generalily have shown that with some flow and front crossheader pressure avallable following the reactor scram adequate heat transfer conditions will exist. The demonstrati on of adequacy stems from observations that surface temperatures of the heater rod do not exceed the melting point of aluminum. Single tube events as severe as an instantaneous $80 \%$ reduction in flow at $1250 \mathrm{KW}$ power level have been Investigated and the data show that f1lm bolling w1ll not occur in a K-Reactor fuel channel as long as the Panellit gage scrams the reactor within 3 to 5 seconds after the flow loss.

These are very severe conditions and their cautious application to the total reactor would indicate that the reactor could handle a sudden decrease in flow of up to $15 \%$ without fuel burnout or serlous reactor damage. Caution is indicated primarily because In a total reactor flow reduction a large number of high power tubes are involved in the transient, and the effect of parallel channel flow on burnout conditions has not been deternined.

\subsubsection{Analytical Methods}

For constant water-film coefficient and fuel physical properties, strictly theoretical solutions have been developed for the fuel temperatures as a function of time after a reactor scram. These generally yield a summation of Fourier and Bessel function series solutions. However, for the case of variable water film coefficient and two-phase flow no strictly theoretical solution is known by the authors. It is possible, by means of an

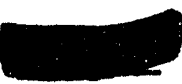


Iterative method and machine calculations to obtain a reasonable approach to actual conditions in most cases.

In general, there are two cases of concern:

a) Sub-cooled burnout of a fuel element at high heat flux, and

b) Unstable bolling followed by a rapld flow decrease leading to film bolling and fuel channel burnout.

In the case of sub-cooled burnout, the heat flux (heat leaving the fuel surface per unft area, $q / A$ ), is a function of:

1) The local coolant pressure,

2) The amount of sub-cooling, 1.e., coolant bolling temperature minus the coolant local temperature,

3) The coolant velocity, and

4) The coolant channel equivalent diameter.

A recent report(6) presents an empirical equation, based upon many different burnout studies on unfformly heated geometries, in the form:

$(q / A)_{\text {B. } 0 .}=\alpha \frac{\left(1+\beta_{0} T+\beta_{1} T / D\right)\left(1+\gamma_{0} V+\gamma_{1} V / D\right)}{1+\delta_{1 / D}}$

Where: $(q / A)_{\text {B.O. }}=$ probable burnout heat $\mathrm{flux}, \mathrm{MW} / \mathrm{ft}^{2}$

T - Amount of sub-cooling ( $t$ saturated - $t$ bulk) at given channel position $-{ }^{\circ} \mathrm{C}$.

$D$ - Equivalent channel diameter - ft.

$V=$ Coolant velocity - ft/sec.

and $\alpha, \beta_{0}, \beta_{1}, \gamma_{0}, \gamma$, and $S_{1}$ are corre-

lating functions given in the report as a function of local coolant pressure.

Based upon a study of the data spread in this correlation it is concluded that $60 \%$ of the value calculated in Equation (1) represents a conservative IImiting reactor heat flux. This correlation was applied to experimental runs on the $\mathrm{K}$ geometry made in the Hanford Thermal Hydraulics Laboratory with the following results. (7) 


\begin{tabular}{|c|c|c|c|c|}
\hline $\begin{array}{l}\text { Flow } \\
\text { grom }\end{array}$ & $\begin{array}{c}\text { Bulk Temperature } \\
\bullet \mathrm{C} \\
\end{array}$ & $\begin{array}{c}\text { Pressure } \\
\text { psig } \\
\end{array}$ & $\begin{array}{l}\text { (q/A) Exp. } \\
\text { BTU/hr } f t^{2}\end{array}$ & $\begin{array}{l}\text { (g/A) Cals. } \\
\text { BIU/hr ft }\end{array}$ \\
\hline 50 & 93.2 & 25 & $1.25 \times 10^{6}$ & $1.26 \times 10^{6}$ \\
\hline 20 & 93.2 & 25 & $0.83 \times 10^{6}$ & $0.82 \times 10^{6}$ \\
\hline
\end{tabular}

Where $9 / \mathrm{A}$ cale. $=.60(\mathrm{~g} / \mathrm{A})_{\mathrm{BO}}$ from Equation (1).

The reference describing the Hanford burnout tests (7) pointed out that although these burnout heat fluxes were evidenced by a rise in heater rod temperature, the temperatures were not extreme and stable operation continued without melting of the heater rods. In the $20 \mathrm{cpm}$ case, for example, operation was stable at $1,000,000 \mathrm{BTU} / \mathrm{hr} \mathrm{ft}^{2}$ and maximum measured rod temperatures were $593^{\circ} \mathrm{C}$ which is below the melting temperature of aluminum. Thus, these limited data indicate that $60 \%$ of the value obtained from Equation (1) gives conservative estimates of sub-cooled bumout conditions in Hanford reactor geometries.

In the case of flow instablity the situation is even more empirical than for sub-cooled burnout. In this range, however, there 18 a great deal of laboratory data which has been used to establish burnout conditions. From these data in empirical: technique has been developed which conservatively predicts the point where unstable flow conditions are initiated in a process tube. Th1s technique employs "bolling curyes" which are plots of inlet pressure versus flow or outlet temperature for any particular hydraulic system but at constant power, inlet temperature, and discharge pressure. It represents a hydraulic system demand curve in that it gives the pressure required to maintain a given flow rate regardless of supply characteristics. The relationship between the supply chracteristics and the bolling curve determine the flow conditions which exist in the tube. This is described more fully in the Appendix. A method for calculating boiling curves which give conservative values of the flow rate where unstable flow begins has been described by McEwen and Batch. (8) The method is based on the principle that in the Hanford hydraulic system, the maximum possible increase in pressure drop due to bolling is that corresponding to a hypothetical increase of the discharge duct pressure just sufficlent to quench boliling. Thus, tube inlet pressures are calculated by adding together the single phase pressure drop across. the active and dumny sectlons of the tube and the discharge pressure necessary to prevent bolling at the tube exit. Calculated on this basis, the curves provide pressures which equal or exceed the actual pressures associated with any flow rate in the $K$ geometry. This is confirmed by comparisons with experimentally determined bolling curves. The method calculates tube inlet pressure by the following expression: 


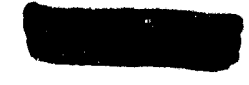

$-10-$

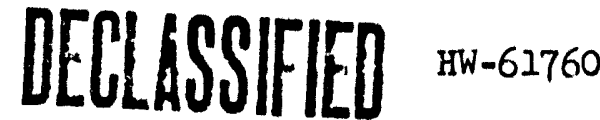

\author{
$P_{F}=K F^{l .8}+(f) P_{R}$ or $P_{S T O}$ \\ Where $P_{F}=$ Tube inlet pressure, psig. \\ $P_{R}=$ Discharge duct pressure, psig. \\ $K$ - Proportionality constant depending on the geometry \\ of the system. \\ $\mathbf{F}=$ Flow rate at tube inlet, gpm. \\ PSTO = Saturation pressure corresponding to the tube \\ outlet water temperature. \\ $(\ell)=$ Indicates "whichever is greater".
}

Using this technique a boiling curve may be constructed such as shown in Figure 1 , in which the tube inlet pressure required to maintain a glven flow at constant power, tube inlet temperature, and discharge pressure is plotted as a function of the square of the flow rate. Plotted in this way the supply curves may be shown on the same plot as stralght lines. The relationship between the supply and demand curves determine the Instantaneous flow-pressure conditions which are present in the tube. With reference to Figure 1 , the intersection of the normal supply curve FA. with the demand curve at (A) gives the normal equilibrium operating point. The supply pressure at zerc flow is the front header pressure $(F)$.

When the operating point (A) falls on the straight section of the bolling curve the flow 18 all in the liquid phase. As the flow is reduced the pressure required decreases as a function of the liquid-phose pressure drop. The bolling curve deviates from this straight line when bolling begins in the rear fittings. As the flow is further reduced increased amounts of steam are formed until a minimum point is reached on the boiling curve where the increase in pressure drop due to steam formation just balances the decrease in pressure drop due to liquid-phase pressure drop. With further decreases in flow, bolling progresses farther upstream towards and into the active section and the pressure nises sharply.

The effect of a sudden flow loss is evaluated by using line AR wh1ch approximately represents the flow-pressure relationship at constant outlet water temperature. With a rapid flow decrease, the outlet water temperature remains constant for the few seconds required for bolling to occur in the rear fittings to cause a rise in pressure and further decrease in flow shown at the intersection of the new supply curve with the boliling curve. If after a flow reduction the pressure avaliable exceeds the pressure required to

* See Page 14. 
maintain that flow constant the flow is stable. Any flow greater than that at point B in Figure 1 is a stable operating point. Point $B$ is the point of inciplent flow instability, or the flow at which instability is inftiated at the supply pressure shown for a rapid flow loss. At a hlgher supply pressure this point occurs at a lower flow. At llow rates below this value the supply pressure is not sufficlent to overcome the increased resistance to flow due to bolling and the flow suffers a further self-induced rapid reduction to very low values where fuel burnout can occur if the reactor 18 not shut down shortly after the instant of change. Thus, the reactors must be operated so that conditions of inadequate flow are immediately detected initlating a reactor shutdown.

\subsubsection{Transient Events w1th Potential for Burnout}

Under steady-state equilibrium operation, the limitation of nol bulk bolling supplies ample protection aginst fuel burnout For the usual reactor scrams the power level 1 is reduced before the reactor flow and the burnout potential is continuously reduced during such transients.

The signiflcant reactor events which under improbable conditions could lead to fuel burnout are the following:

1) Electrical power fallure to the process pump motors.

2) Ioss of a pump shaft or rupture of a process IInes.

3) Reactor power level ourge such as could be caused by the inadvertant complete withdrawal of two control rods at maximum speed.

Laboratory data have shown that no fuel burnout w1ll occur at flow rates greater than the flow at whlch unstable flow occurs in the process tube. Even after flow instability, a finite time exists before film bolling occurs, depending on the severity of the flow reduction and inftial power level. The potential for burnout while the water is sub-cooled is very low because the cosine heat distribution along the charge means that the heat flux 18 less than $200,000 \mathrm{BTU} / \mathrm{hr} \mathrm{ft}^{2}$ at the location of near saturated conditions. A comparison between the operating heat flux and the sub-cooled burnout heet flux under various conditions is shown in Table II. At an equilibrium level of $1500 \mathrm{kw} /$ tube a safety factor of $2.41 \mathrm{~s}$ calculated. Under emergency transient conditions, and assuming the conditions existing at the worst time during the translent are in the steady-state to make the calculations, Table II shows that sub-cooled burnout conditions wili not be exceeded. It 18 concluded that sub-cooled burnout w1ll not occur at the $\mathrm{K}-$ Reactors under emergency transients. These data further indicate that sub-cooled burnout will not be a problem in Hanford reactors unt1l power levels are considerably above present levels. The problem of bolling burnout assoclated with flow instability represents the prime hazard. 


\section{Flow Instablilty}

Based upon laboratory data a serles of charts bave been prepared showlng the relationship between cooling demand and the coolant supply pressures following varlous accidental K-Reactor incidents. Flgure 1 shows the potential for flow instability in K-Reactor process tubes following a BPA power fallure for elther 5 .or 6pump operation. A maximum power level of about $1250 \mathrm{kw}$ w1ll be obtained with 5 pumps when the inlet temperature $1820^{\circ} \mathrm{C}$. The present peak power with 6-pump flow $181500 \mathrm{kw}$ besed on fuel element rupture behovior. The supply curves in Figure 1 give the pressure avaliable as the flow decays following the loss of pumping poiver. The dewand curve gives the equilibrium pressure required varlous reactor flow reductions to maintain flow at the new value. The 1sothermal line. (AR) shows the approximate. decrease in flow due to a sudden 1088. An additional decrease in Flow due to boling pressurization in the fear fittings after a step flow decreased in show by the intersection of the new supply curve with the steady-state demand curve.

\section{TABLE II}

APPROACE TO SUB-COOLED BURNOUT CONDITIONS DURING TRAIISIFNT OPERATION AT K-REACTORS

\begin{tabular}{|c|c|c|c|c|c|}
\hline Operating Condition & $\begin{array}{l}\text { Trube Flow } \\
\text { (Bpm) }\end{array}$ & $\begin{array}{l}\text { Tube Power } \\
\text { (kw) }\end{array}$ & $\begin{array}{l}(\mathrm{q} / \mathrm{A})_{\mathrm{Mgx}}^{(1)} \\
\left(\mathrm{MW} / \mathrm{ft} \mathrm{t}^{2}\right)\end{array}$ & $\begin{array}{l}(\mathrm{g} / \mathrm{A})_{\mathrm{B} .0 .} . \\
\left(\mathrm{MW} / \mathrm{ft} \mathrm{t}^{2}\right.\end{array}$ & $\frac{q_{\mathrm{Max}}(2)}{q_{\mathrm{B} .0}}$ \\
\hline Equilibrium Operation & 58 & 1500 & .17 & .42 & .41 \\
\hline BPA Fallure ( $\beta)$ & 49 & 1500 & .17 & .35 & .49 \\
\hline Loss of One Pump (3). & 47 & 1500 & .17 & .30 & .57 \\
\hline Loss of Two Pumps $(3)$ & 35 & 1500 & .17 & .20 & .85 \\
\hline $50 \%$ Power Surge $(3)$. & 58 & 2250 & .25 & .34 & .74 \\
\hline
\end{tabular}

(1) Maximum operating heat fiux at polnt of closest approach to sub-cooled burnout conditions in tube.

(2) Ratios greater than 1.0 indlcate sub-cooled burnout conditions have been reeched.

(3) Calculations made at point in transient where burnout heat fluxes are at their lowest values. A 3 second interval between infitiation of transient condition and reactor scram was assumed.

The flgures are for the infitial perlod where the reactor flow is decreasing at a constant reactor power level, before an effective scram has been achieved. The criterion for conditions of stable 


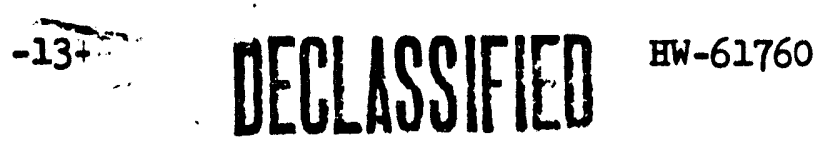

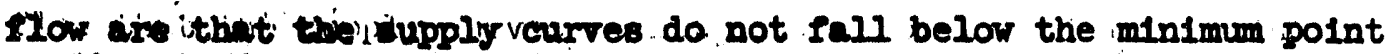
on the steady-state demand curve before the instant of effective reactor scram. The sharp drop in heat generation following the scram w1ll assure that the supply exceeds the demand thereafter. As shown in Figure $1 ;$ if the resctor is effectively scramed within 4 seconds after BPA fallure in the case of elther 5 or 6 pump operation, flow Instability will be avolded. In the actual case, a scram is effective following a BPA fallure after about 2 seconds.

It should be polnted out that flow Instabllity does not necessarily mean channel burnout. A finfte time exists between the onset of instability and the onset of 11 lm bolling in the process tube.

F1gure 2 shows the effect of a line rupture or pump shaft fallure on flow 1nstablilty. Under these conditions the total flow change occurs withln one second while the reactor would not be effectively scrammed for two seconds. The scram would be initlated in less than one second after the instant of change through a low Panellit eage trip. 'Consequently, the new supply curve must be higher than the minimum point on the demand curve to avold flow Instablilty. This corresponds to aximum flow decrease of $18 \%$ for 5 -pump operation and $21 \%$ for 6-pump operation. As shown in Figure 2, loss of flow from one pump can be sustained without experlencing unstable flow conditions in any process tubes, while loss of two 0. Ire or two of $81 \times$ leads to flow instability in many reactor channels. It should be stressed that this does not mean that bolling burnout would occur under these cond1tions.

Recent laboratory tests have been run wherein the inlet flow line to a olmulated $K$ fuel channel was suddenly opened. ( 3 ) Th1s reduced the inlet pressure to aefo psig and fuel cooling was obtained by beck flow with pressure driving force of 16 to 38 p81.. Under these test conditions no fuel burnout was obtalned at rear header pressures in excess of $30 \mathrm{ps} 1 \mathrm{~g}$.

The loss of reactor pump-sets reduce the header-to-header pressure drop down to the values shown below:

a) One of s1x pumps: $300 \mathrm{pB} 1$.

b) One of I1ve pumps: 177, p81.

c) Two of s1x pumps: 287 pB1.

d) Two of five pumps: 120 pB1.

The driving force in all of these cases is well above that required experimentally to prevent fuel burnout. These experimental tests must be qualleled to the following extent:

a) X-Reactor central tube powers are up to $1500 \mathrm{kw}$ (with 6 pumps) and these tests only went up to $1000 \mathrm{kw}$. 
$-14$

FIGURE 1

-I REACTOR BPA LOSS-

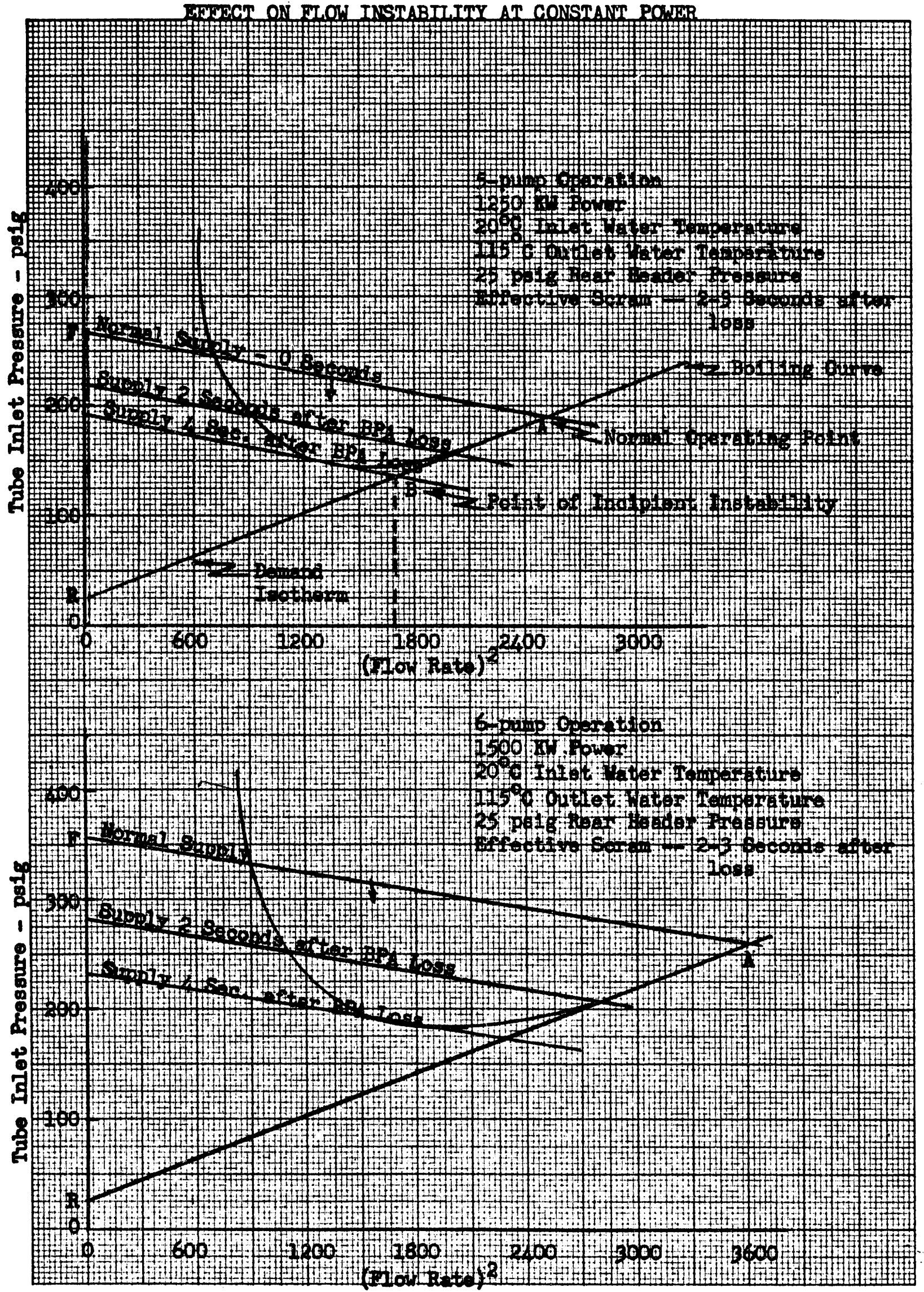




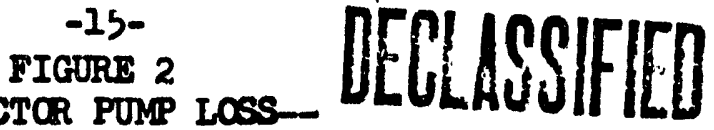 \\ BW -61760 \\ EFTECT ON FLOW INSTABIIITY AT CURRENT PONER}

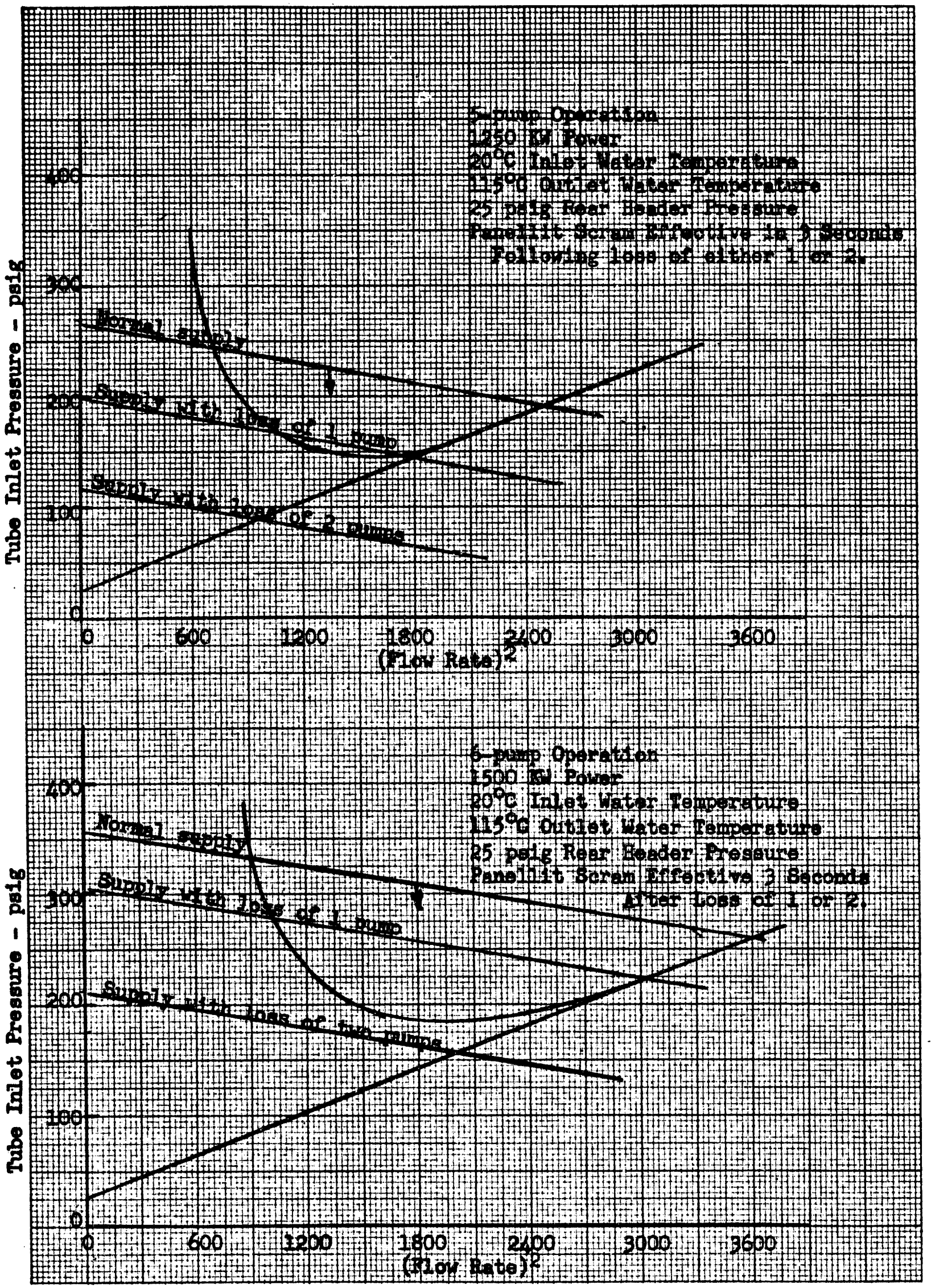


b) The heat supplied to the coolant amounted to only about 55 to 70 percent of that expected in the reactor:

c) The onset of hydrodymamic instability between parallel fuel channels in the reactor might cause burnout in one or more channels when average conditions are safe. (Parallel channel flow is belng studied to evaluate this potential.)

Therefore, it appears prudent to operate in a manner that will prevent our reaching the conditi on of unstable flow in any fuel channels.

The third type of event, the effect of a power level surge on instabillty 18 shown in Figure 3. Here, there is only one supply curve and the demand curves increase with power level. The criterion for stable flow conditions is that the reactor be shutdown before the supply curves fall below the minimum point on a steady-state demand curve. Figure 3 shows that unstable flow conditions are inftiated after more than a $28 \%$ power increase for the 5-pump case, and more than 35\% increase for 6-pump operation. It is expected that bolling pressurization plus the effect of reduced flow rate caused by the increased bolling will inftiate a high Fanellit trip before unstable flow conditions are reached. However, the time sequence of this translent 18 not known, and the power level will continue to increase after detected by a Panellit gage for the 2 to 3 seconds required for effective shutdown. If the surge is large enough and sufficlently rapid, flow Instability could occur in a lew tubes during the 2 to 3 second interval required to effectively scram the reactor after reaching high trip conditions. An analysis by G. R. Parkos indicates that a local power level surge as high as $90 \%$ may occur if two top control rods were inadvertantly withdrawn and the reactor not shutdown. Thls my occur because the Beckman flux monltor chambers wh1ch are normally expected to detect this situation are situated in the bottom of the reactor and are shlelded by other control rods and poison colyums from seeing all but a small portion of. the power increase. (8) Bven under these extreme conditions it is expected that the Panellit system will inftiate a reactor shutdown in time to prevent fuel jacket melting. Again, uncertainty arlses as to possible mult1-channel effecț. The occurrence of a power surge requires a gross operating error or the highly improbable event of 1088 of a rear cap on a polson columan tube whlch will permit the polson column to discharge. Also, the installation of improved nuclear Instrumentation is scheduled which w1ll reduce the magnitude of possible power level surges below those which inftlate unstable flow conditions in individual process tubes. 
- I RaActar POWER SURGE-

MTYPCT ON FIOW INSTABITITY AT CONSTANT PONOR

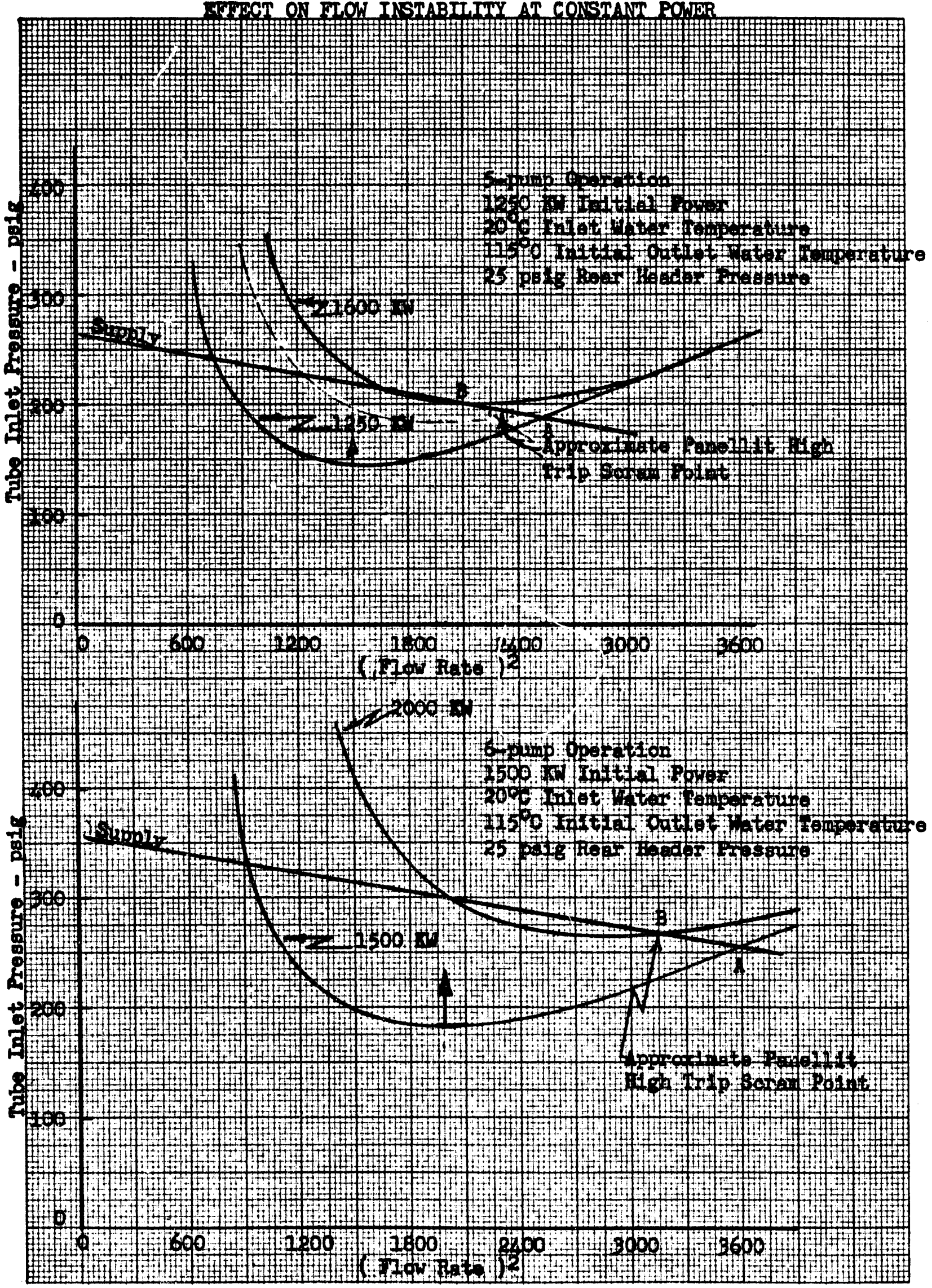




\subsubsection{Research and Development Programs}

\section{DECLLSSFIFE}

The laboratory work on this general problem is continuing. A major laboratory modification project has been completed that permits power level increases from the present limit of $1250 \mathrm{kw}$ up to a maximum of $2500 \mathrm{kw}$. Studies to be conducted in the coming fiscal year include the followlug:

a) Investigation of the effect of the loss of a front connector, 1.e., low tube powerfreverse flow studies of the K-Reactor geometry.

b) Steady-state and transient bolling curves for the $K$ geometry at the higher tube powers.

c) Effects of 1088 of flow through plugging upstream of the Panellit gage.

d) Definition of conditions leading to sub-cooled heat transfer burnout for all reactor geometrles intluding the effects of eccentric slug loadings and non-uniform heat Plux.

This program 18 malaly directed towrars single tube incidents. Although the probability of a single tube incident appears considerably greater than a total reactor event, the potential hazards of the latter are very much greater. Therefore, laboratory studies will include investigation of the following events:

a) A rapld reduction in front header pressure by means of the programmed opening of a by-pass valve.

b) A programmed rapid increase in power level at constant front header pressure.

c) Invest1gation of the possible aggravation of channel flow Instablitty caused by parallel channel dynamic effects.

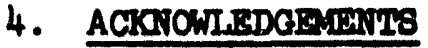

The authors w1ch to express the1r appreclation of the cooperation of J.M. Batch in the use of the Thermal Bydraulics Unft's laboratory data and of. the belpful revlew and comments by F. W. VanWormer, and G. M. Besson.

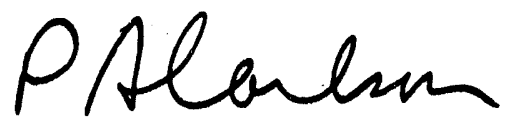

P. A. Carlson Reactor Englneering Unit RESEARCH \& ENGINHEERING SECTION

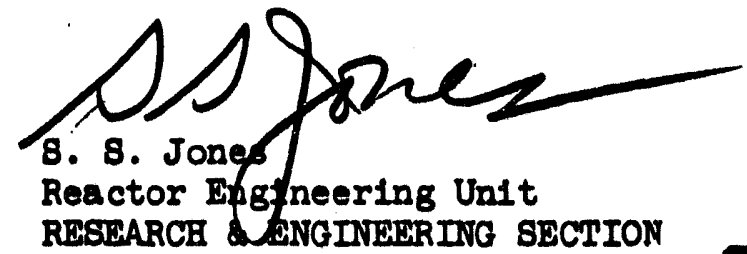


REMRRATCES

1. EW-56621, Experimental Results of Test 81mulating Plugging of a K Tube With Ior 81ugs, G. M. Hesson and D. E. Fitzs1mons, July 7, 1958 (Becret)

2. HW-60518, K-Reactor Panellit Protection Agrinst Plugging Incldents W1th Low Front Beader Pressure, G. M. Hesson and D. E. Fitzsimons, June I, 1959 (Becret)

3. BW-61849, Report on Prel1minary Iaboratory Experiments Invest1gating Consequences of Fallure of Front Bydraulic Fittings in K-Reactor Geometry, G. M. Hesson and D. E. F1tzsimnons, September 9, 1959 (Secret)

4. EW-64029, Extended Eydraul1c Demand Curves for K Geometry Tubes W1th I\&E Fuel Blements, G. M. Hosson, et al, February 25, 1960 (Becret)

5. BN-54369, BAPO-284 Bhutdown Reports, by.V. H. Clark, January 6, 1958, (secret)

6. DP-363, Burnout of Beating Burfaces in Water, R. L. Menegus, March, 1959.

7. Batch, J. M., Nonthly Report, Thermel Hydraul1cs Operation, August, 1959, August 29, 1959 (Condffential-Undocumented)

8. HW-42469, Method of Rmplrical Calculations of Bolling Curves, by I. H. Matwen and J. M. Batch, June 21, 1957 (Becret).

9. BW-51655, 8pecif1cat1on A-020 Process Tube Instability IImits, by K. W. Hess, July 22, 1957 (Becret)

10. BW-64417, Revlew of the Status of Hanford Reactor Bmergency Cooling, S. S. Jones, June 1, 1960 (Secret) 


\section{Discussion of Trpical Bo1ling Curves}

In the bast several years the laboratory forees in the Thermal Bydrauclics Unit have obtalned some very valuable date on the flow transients that accompany sudden imposed flow reductions with the fuel channel maintalned at constant power level. Before translating these to the reactor, it is in order to sumarlize the flow Instablilty problem and how it 18 handled at Banford.

Let us examine the relationship between the flow supply or pressure available to a process tube and the pressure required to malntain a given flow rate constant at a given tube power. Consider the curves shown below in Figure A-1.

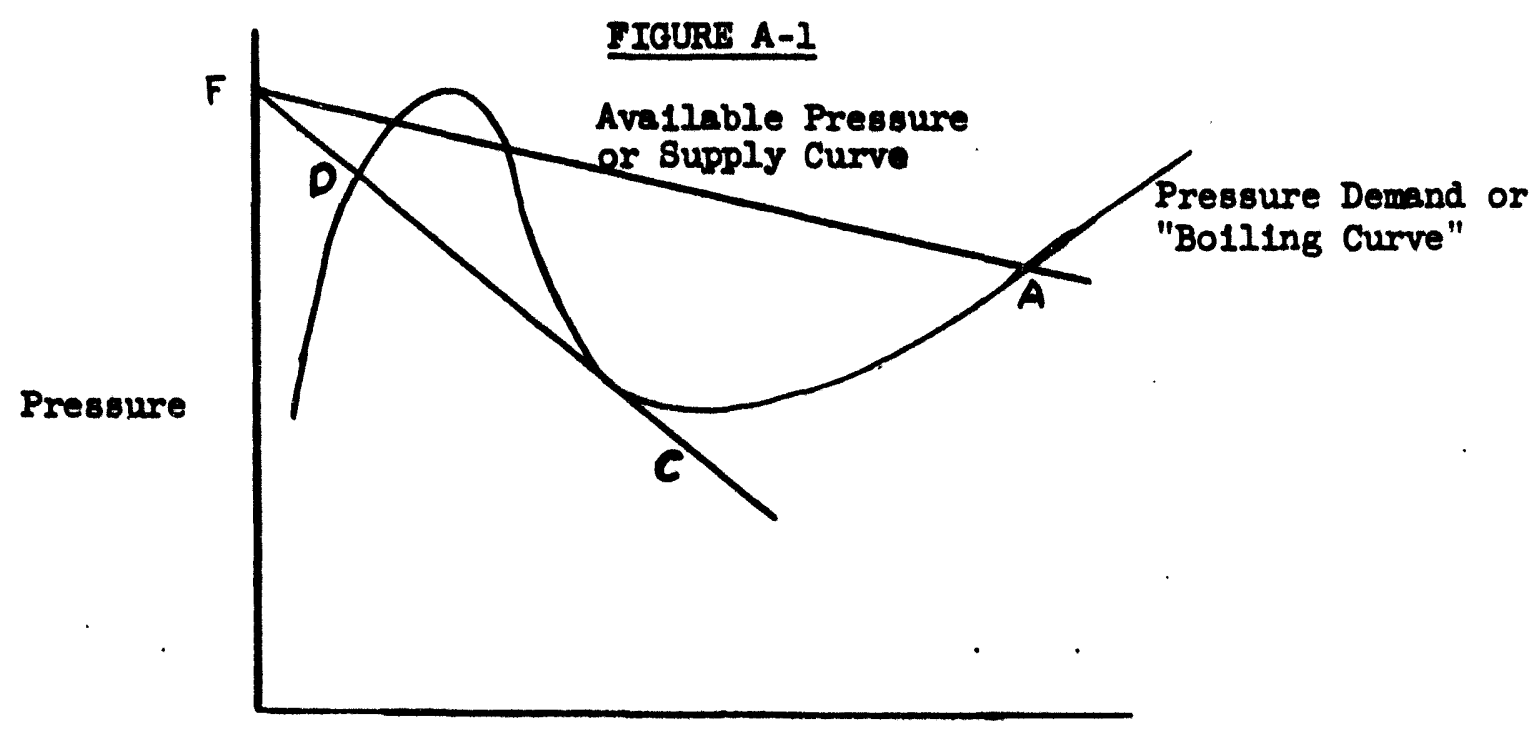

Square of Flow Rate

The bolling curve represents the pressure required for the indicated flow rate at constant power, lnlet water temperature, and discharge pressure. When the operating polnt (A) falls on the stralght section of the bolling curve the flow is all in the liguid phase. As the flow is reduced the pressure required goes down $a 8$ the 11quid-phase pressure drop 18 reduced at lower flow rates. The demand curve deviates from this stralght line when bolling begins in the rear flttings. As the flow is further reduced increasing amounts of steam are formed as bolling progresses farther upstream from the rear fitting At polnt (B) the decrease in liquid phase pressure drop is balanced by the increese in two-phese pressure drop due to bolling in downstream sectlons of the system. With further decreases in flow, bolling progresses toward and into the active section and the pressure rises sharply 
unt11 a peak pressure 18 reached. At th1s point the higher pressures reduce the rate of coolant volume increase associated with bolling and further reductlons in flow result in a decreased pressure requirement.

The line (FA) represents the normal supply characteristlcs or pressure avallable to the process tube as a function of fluw. The intersection of the supply line with the demand curve defines the process-tube normal operating pressure and llow. To be stable the Intersection must be such that if the flow rate were to be decreased slightly, more pressure would be avallable than required, and the rate would return to 1 ts previous value. Continued stable operation with different degrees of bolling in the tube is possible only if such a stable operating point exists. If the pressure avallable 18 less than pressure required as shown by supply line (FC), no stable operating polnt exists except at very low flow rates (polnt $D$ ) and the flow rate suffers a further seif-induced reduction to point (D). Although (D) represents a stable operating point, high steam qualities are present in the tube and unless the reactor is shutdown heat transfer burnout occurs. This self-Induced flow reduction is known as flow Instabllity, which will lead to fuel element melting if the reactor is not repldiy shutdown when it occurs in a single tube in the reactor.

Application to Process Tube Protection

As shown above, it 18 possible to 1dentify conditions of adequate and inadequate flow on the basis of general reglons of the bolling curve. It is possible further to detect the transition from one region to another by high or low inlet pressure trips to scram the reactor when conditions of inadequate flow occur. The rapid reduction in power generation following the scram restores adequate single phase cooling and fuel element melting is prevented. Th1s is accomplished at Banford by by measuring the pressure at the throet of a venturi or orfelce located between the front crossheader and the tube Inlet nozzle with a Panellit gage. Disturbances in flow or power are indicated by elther a high or low pressure reading. Instrumentation is set to trip the reactor whenever the pressure Indication exceeds the set polnts by a certain amount.

It 18, of course, extremely Important that the Panellit gages and assoclated clrcultry be reliable, "fall-safe", and responsive to changes in pressure. Laboratory tests bave shown that the gages adequately perform this function. Gage response is not too critical in the case of plugging events downstream of the Panellit tap because the Increased pressure losses associated with two-phase flow supplement the added pressure 108 from plugging and causes the Panellit pressure to Increase. The case of sudden plugging upstream of the Panellit trip is of more concern. In th1s case the pressure is first reduced depending on the degree of flow reduction, and then, in the case of flow reductions beyond the point of Instablifty, Increases rapldiy as the amount of bolling increases at the tube outlet. If this increase in pressure is rapid enough or the cage sluggish a low trip may not occur. Bowever, laboratory data bave shown that the rapid pressurization results in a high trip in sufficlent time to prevent burnout even if the low trip does not occur for the upstream event.

Pasell1t trip settings are applied so that a high pressure trip w1ll occur at or before conditions of flow Instablilty are inftiated in the process tube in the

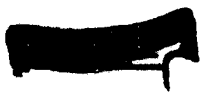


event of a flow restriction downstream of the polnt of pressure measurement. The most probable event for whlch these trip settings are needed is the swelling of a fuel element fallure. Low trip settings are established to 1nltlate a reactor shutdown at or slightly beyond the polnt of flow 1nstabllity inltiated by a rapid flow reduction caused by a disturbance upstream of the point of pressure monitoring. In both cases, the trip will occur in sufficlent time that if some flow and front crossheader pressure 18 avallable after the shutdown; adequate cooling w1ll be 8 upplied to the process tubes to prevent fuel element jacket melting.

A large safety factor exists in these instabllity limits through the assumption that plugging occurs just to the point of instability because more severe plugging would result in a greater drop in Panellit pressure, and from the fact that laboratory experiments have shown that the reactor scram can safely be delayed unt1l after instablilty occurs in the process tube and the reactor shut down by a high pressure trip. Thus, the hligh trip provldes backup to the low trip for most cases of upstream plugging.

To verlfy that reactor scram settings do indeed protect against fuel jacket melting requires a knowledge of the pressure-flow relationship as a function of time or translent experimentations. Transient experiments simulating sudden plugging upstream of the polnt of pressure monltoring bave been run at tube powers up to $1250 \mathrm{kw}$ and $125^{\circ} \mathrm{C}$ outlet temperatures for $110 \mathrm{w}$ reductions to $3 \mathrm{gpm}$. A typlcal flow chart is shown in Figure A-2. The time curves were plotted from pressures obtained as a function of time following given flow reductions holding the front header pressure constant. For example, for an infital flow reduction to point $(0)$, instablifty occurs in the process tube. There follows a self-aggravated flow reduction to the film boling condition which is a stable operating point. Immedlately following the applled flow reduction the pressure 18 shown by the Intersection of the plugged supply line ( $F O$ ) and the Intersection of the zero second line. 8imilarly, the pressure-flow relationship 1s shown for varlous other times after the flow reduction. A film bolling condition 18 shown to occur about seven seconds after the flow loss. A flow reduction in which a 1088 of front header pressure also occurs 18 shown by the supply line F'O. Th:s roughly represents the case of 108s of two pumps at 5-pump operation. The effect of also reducing the front header pressure 18 evident in the decreased time to reach film bolling. Also, these data indicate that a low trip must occur to prevent damage for there may not be sufficient pressurization to also cause a high trip. However, in an Incident such as this which effects a great many tubes, it is inconcelvable that all Panellit gage low trips w1ll be 1noperative. Although a trip is assured, f1Im bolling w1ll probably take place in some tubes and, thus, the chart indicates that some fuel darrage may occur in severe 1ncidents of thie type if there is a 81 galflcant mult1-channel effect. Further data of this type w11l be obtained to Invest1gate flow reductions in whlch a decrease in front header pressure occurs. 


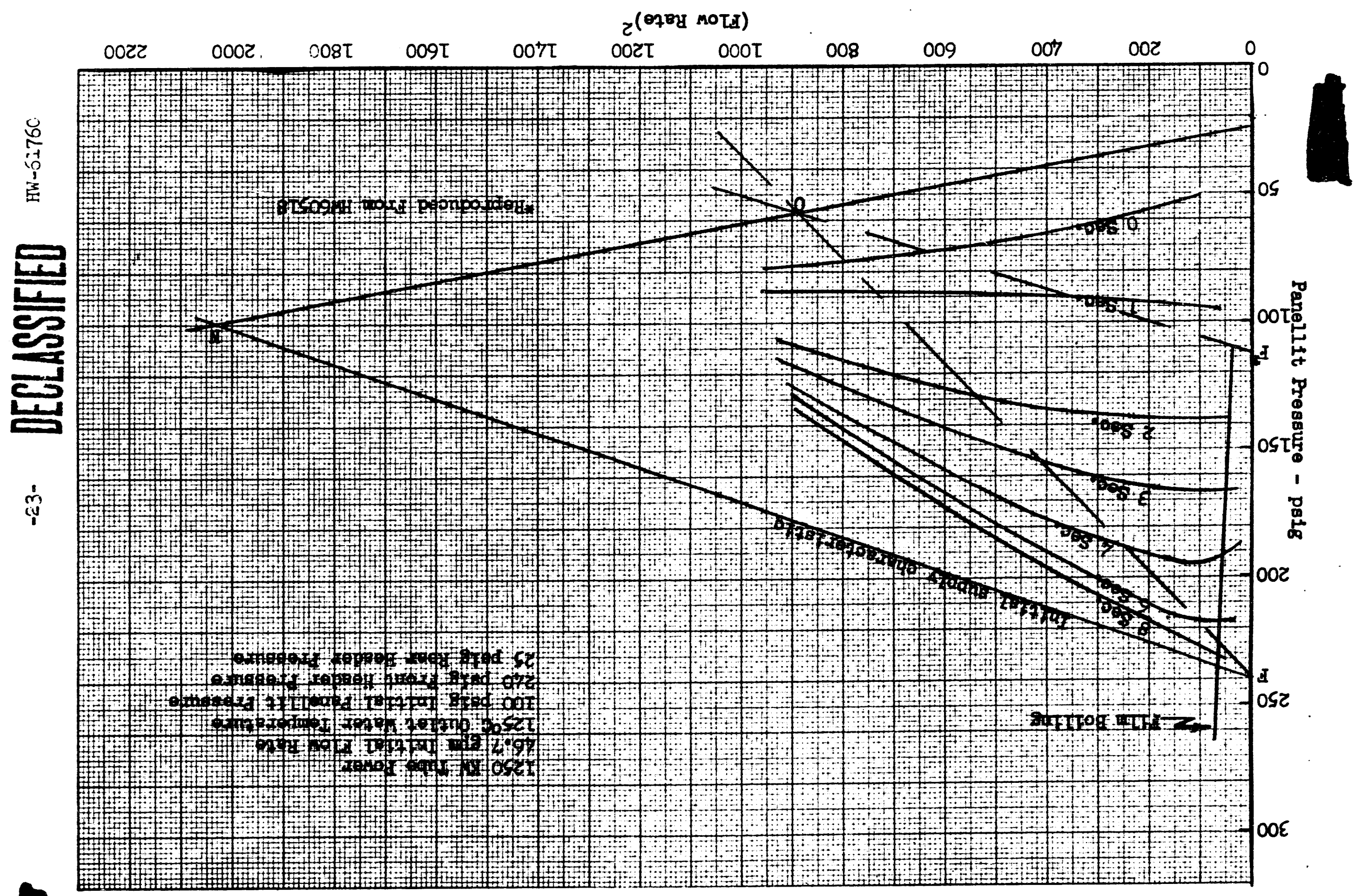

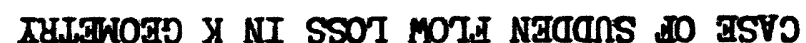

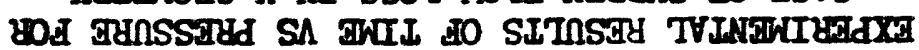
ट-V gunगIS 

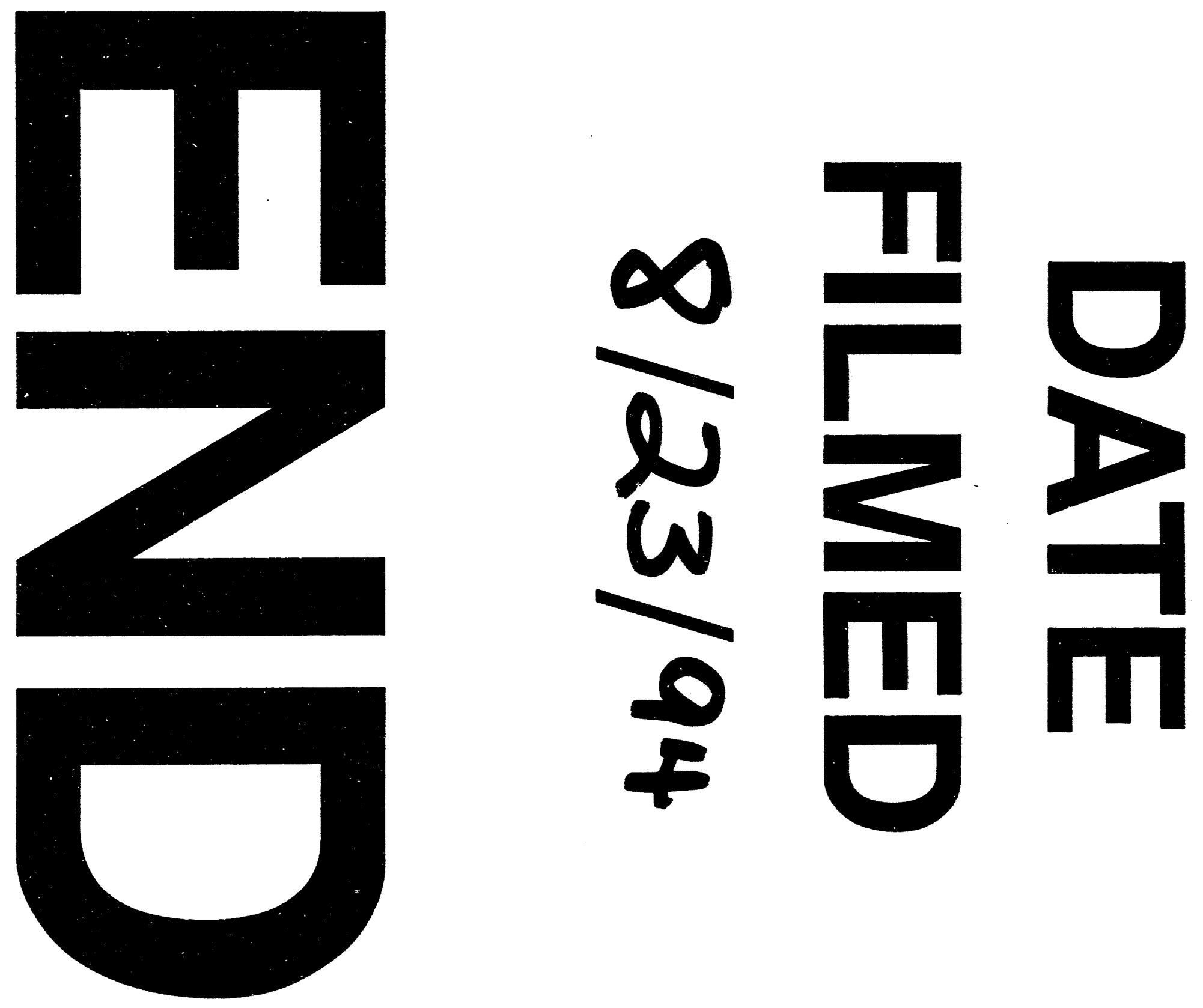

H 